\title{
FOREWORD
}

\section{PUBLISHING IN KENYA}

\author{
HENRY CHAKAVA
}

\section{Survey of the literature}

There is no book that I am aware of which comprehensively covers the topic of publishing in Kenya. The best effort so far is J. W. Chege's, Copyright Law and Publishing in Kenya (EALB, 1978) but unfortunately, Chege does not allow himself sufficient breadth or depth to cover the topic adequately. John Ndegwa's MA thesis, 'Printing and Publishing in Kenya', contains some useful background information, particularly about the role played by missionaries in spreading the printed word into the Kenya interior. Various papers by John Nottingham and Charles Richards give some insight into the Kenya Publishing situation in the 1960s. A book recently published in the US under the title Publishing in the Third World, by Philip Altbach, has an essay on Kenya.

Since 1973, the writer has presented various papers at international conferences, some of which are listed in the bibliography at the end of this Foreword.

\section{Introduction}

It is not possible to say exactly when the printed word arrived in Kenya. Mombasa has been a port linking Africa, India and the Far East for many years. The traders who bought and sold goods in Mombasa and around the Indian Ocean must have used Arabic script. But the Berlin Conference of 1885 changed all that. East Africa fell under the suzerainty of the British. They brought their administrators, their settlers and, of course, their missionaries to help them conquer the souls of the recalcitrant Africans.

Armed with the Bible and the hymn-book, and spearheaded by the Church Missionary Society, they moved into the interior, setting up mission stations, learning the language of their would-be converts, translating their Bible and hymn-book into African languages and generally 'civilising' and 'pacifying' the natives.

This trend went on until after the Second World War, following which Britain found it economically necessary to revise her imperial policies. She started to encourage the manufacture of some of her goods in the colonies in an effort to counter competition from Japan, West Germany and the US, which were industrialising faster than Great Britain. This shift has been convincingly argued in Nicola Swainson's The Development of Corporate Capitalism in Kenya (1980). Instead of importing books, for example, a decision was made to establish the East African Literature Bureau in 1947 under the leadership of Charles Richards, who had already proved his publishing capability with the CMS bookshop-where he had been able to persuade his employers to set up a commercial publishing house under the name 'Njia Kuu Press' ('The Highway Press'). This press, which may have existed between 1940 and 1949, was very active in encouraging African authorship, and folded shortly after Richards left CMS to set up the East African Literature Bureau in 1948. Amongst its other aims, the Bureau was charged with the responsibility to:

(a) publish books for Africans both for general reading and educational purposes, in English and in African languages;

(b) edit and publish popular magazines;

(c) actively encourage and assist African authorship;

(d) assist in the development of book distribution;

(e) establish and administer a lending-library service for African readers. 
The Bureau's headquarters were in Nairobi but it had branches in Kampala, Dar es Salaam and Zanzibar. It published many books and was assisted in this exercise by the East African governments who provided it with annual subsidies to enable it to underwrite some of its losses on unviable but essential titles, especially those written in African languages.

It was instrumental in encouraging international commercial publishers to set up in Kenya, passing over to them the rights to books which had already succeeded in the market, while concentrating on the less profitable areas of developing adult literacy primers and readers, and other reading material for new literates, particularly in African languages. It also helped in the establishment of National Library Services, as required by its articles, in an attempt to get books closer to the predominantly African readership at whom their books were aimed. In line with its policy, the Bureau also developed and supported several journals, passing them on to commercial publishers as soon as they became viable.

\section{The commercial publisher}

Consequent to Richards's policy, Longman were the first British publishers to respond, appointing a regional representative in 1950. Oxford University Press followed suit and even managed to 'poach' Richards to be their local manager in 1954. Through Richards's influence, they were able to obtain rights on the more profitable EALB titles, among them the popular New Oxford English Course for East Africa and the Peak Course, both of which are still in use in East Africa today. Longman's activities were restricted mainly to issuing Kiswahili translations of such titles as Rider Haggard's King Solomon's Mines (Mashimo ya Mfalme Sulemani), R. L. Stevenson's Treasure Island (Kisiwa Chenye Hazina), and the Arabian Nights (Mazungumzo ya Alfu Lela Ulela), to name only a few. It must be understood that although these companies had opened offices in Nairobi, these served only as post offices, conveying back to their London headquarters manuscripts which they considered merited publication.

Local printing did not start until after independence in 1963. Oxford University Press also took on a few journals from EALB such as Azania, Zuka, and the Eastern Africa Economic Review which it eventually shed when these became 'unviable'. Among major books issued

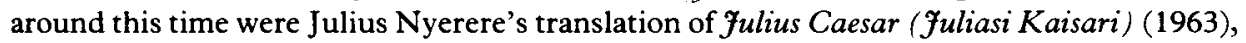
Mau Mau Detainee (Gakaara wa Wanjau) (1983), and his Freedom and Unity (1966), all from Oxford University Press.

Longman, on the other hand, continued to concentrate on the school market, re-issuing courses which had proved successful elsewhere, for example Pivot English by A. Curtis, and Highway Arithmetic by Carey Francis.

\section{Independence and the rise of the state publisher}

From the foregoing, it is clear that at the time of Kenya's independence in 1963, there was no commercial publisher who could have met the aspirations of the newly independent state. Even the educational system itself had to be re-evaluated. The Ominde Commission's Report on education recommended, among other things, the drawing-up of new curricula more in line with the nation's independent status, and the evaluation of the suitability of materials in use in Kenyan schools. It also recommended the establishment of a state publisher to publish, especially at the primary-school level, materials developed at the KIE (Kenya Institute of Education).

The Report was accepted and both the KIE and the Jomo Kenyatta Foundation (JKF) were established by an Act of Parliament in 1965. At the same time, academics from the countries of East and Central Africa agreed to set up the East African Cultural Trust, which in turn set up the East African Publishing House (EAPH), and a printing house, Afropress. 
Within two years of independence, therefore, Kenya had three state-supported publishers - the East African Literature Bureau which continued to publish primers in mother tongues and in other unviable areas, the Jomo Kenyatta Foundation whose brief was to publish, in a near-monopoly capacity, all books for Kenyan primary schools, and the East African Publishing House, which was to publish mainly academic books and fiction. The only area left for the commercial publisher, whether local or foreign, was that of secondary-school books.

Yet in spite of the limited opportunities, more UK commercial publishers arrived on the scene, among them Heinemann Educational Books (1965), Macmillan (1970), Nelson (1962), Evans (1978), Pitman (the 1950s) and Cambridge University Press (the 1960s), to mention only those who set up local offices in Nairobi. Others appointed the locally-based publishers as their agents. The relationship between these foreign publishers and the state publishers was uneasy at best, but usually quite hostile, as the writings by John Nottingham in the 1960 s demonstrate.

In spite of this, however, these two groups managed to coexist largely because although the headquarters of the foreign publishers were in Nairobi, they covered the whole of the East African market. The year 1978 marked a peak of publishing activity in Kenya, as Table 1 shows. Among the popular titles published during this period were Okot p'Bitek's Song of Lawino $\mathcal{G} O \operatorname{Ocol}(\mathrm{EAPH})$ and Charles Mangua's Son of Woman (EAPH), the latter leading to a flowering of popular fiction that produced Maillu's famous After 4.30 and My Dear Bottle. Almost every publisher in Nairobi set up a popular fiction imprint. But all this came to an end after Tanzania closed its common border with Kenya in 1977, a time when Uganda was still going through a stressful period following the Amin coup d'état of 1971.

Table 1 Books and pamphlets published in Kenya, 1977-1987

\begin{tabular}{cccc}
\hline Year & Books & Pamphlets & Total \\
\hline 1977 & 108 & 13 & 121 \\
1978 & 150 & 36 & 186 \\
1979 & 122 & 34 & 156 \\
1980 & 96 & 46 & 142 \\
1981 & 91 & 47 & 138 \\
1982 & 60 & 38 & 98 \\
1983 & 155 & 54 & 209 \\
1984 & 107 & 31 & 138 \\
1985 & 115 & - & 115 \\
1986 & 148 & - & 148 \\
1987 & 160 & - & 160 \\
\hline
\end{tabular}

Since 1977 publishers such as Evans, Foundation Books, Bookwise and Shungwaya have cut their programmes. Amongst the foreign ones Nelson, Cambridge University Press and Pitman have vacated the scene. Currently, the only surviving publishers are Heinemann Kenya, now locally controlled, Longman Kenya, Oxford University Press, Macmillan, Evans and several religious publishers, amongst them Evangel and Uzima Press. The state publishers, the Jomo Kenyatta Foundation and the Kenya Literature Bureau have been given a near-monopoly to publish for schools under the new 8-4-4 educational structure, but they still complain that business is 'not good'. 
With the exception of Heinemann, who are publishing across the curriculum in primary, secondary, and post-secondary institutions, including fiction, children's books and academic books, all the other publishers are concentrating on the more captive school-books market. The University of Nairobi Press, which was set up five years ago with a sizeable grant from British American Tobacco (BAT), has only managed to publish one title during this period.

Yet over the same period nostalgic and euphoric literature glorifying the colonial period has re-emerged. The release of the film Out of Africa has rekindled interest in the first settlers in Kenya. In spite of the numerous books that have been written such as James Fox's Happy Valley (1979) and White Mischief (1982), Errol Trzebinski's Silence will Speak (1979) and The Kenya Pioneers (1985), and so on, my white friends still ask whether I know who killed Lord Erroll! 'Do you think Dennis Finch-Hatton killed himself in that plane crash, or was it a genuine accident?' they want to know. Perpetuating the denigration of the Kenyan people to be found in Huxley's White Man's Country (1935) and The Flame Trees of Thika (1959), and Hemingway's Green Hills of Africa (1936), the tradition still continues, with such books as Shiva Naipaul's North of South (1978).

Since the release of the film Out of Africa these works have become very popular with tourists who come to Kenya. When the film Out of Africa was released in 1986, Karen Blixen's book of the same title, and on which it was based, was reprinted no less than six times, while The Flame Trees of Thika was reprinted four times in 1981 when a film based on the book was released, and even featured on Voice of Kenya (VOK), the national radio and television network.

Turning to autobiographies, biographies and memoirs, the majority of black Kenyans do not fare well either. With the exception of Kenyatta's Facing Mount Kenya (1938) and Suffering Without Bitterness (1968), Oginga Odinga's Not Yet Uhuru (1967), Tom Mboya's Freedom and After, (1963), and The Challenge of Nationhood (1975), Bildad Kaggia's Roots of Freedom (1975) and J. M. Kariuki's Mau Mau Detainee (1983), few Kenyans are forthcoming with their stories. Two other serious books should be mentioned here: President Moi's Kenya African Nationalism (1987), and David Goldworthy's scholarly biography of Tom Mboya, Tom Mboya: The Man Kenya Wanted to Forget (1982). But on the other hand the list of biographies, autobiographies and memoirs of white Kenyans or former settlers is almost endless. To name but a few: Elspeth Huxley, Nellie: Letters from Africa and Out in the Mid-day Sun, My Kenya (1973 and 1985); Michael Blundell, So Rough a Wind (1964); Evelyn Baring, The Last Proconsul (1978); Errol Trzebinski, The Kenya Pioneers (1980); Mary S. Lovell, Straight on Till Morning (1987); George Adamson, My Pride and foy (1986); Beryl Markham, Dispatches from Africa and West with the Night (1979 and 1984); Michael Wood, Different Drums: Reflections on a Changing Africa (1987): Richard Leakey, One Life (1983); L. Farrant, The Legendary Grogan (1981); Karen Blixen, Letters from Africa (1982); Guy Campbell, The Charging Buffalo: A History of the Kenya Regiment (1986); Richard Meinentzhagen, Kenya Diary (1902-06); J. M. Nazareth, The Brown African (reissued 1986).

A legitimate question to ask is: Why has there been a drop in the publishing output by Kenyan Africans at a time when colonial settlers and neo-colonial literature is flowering? Is there a link between the two? I know for certain that white theatre in Kenya today is thriving at the expense of authentic African theatre. The administrators of the National Theatre are reluctant to allow Kenyan playwrights to book the theatre for long periods because they argue that the theatre is usually half-empty when an African play is running. Is this situation also true of publishing? The answer is no. Most, if not all the books referred to above are published abroad, and they find a ready readership in the UK, the US and among the tourists to Kenya and, indeed, wherever the English language is employed. 


\section{The way ahead}

Currently Kenya publishers produce an average of 150 new titles per year. In 1978 publishing reached its peak with 150 new titles and thirty-six periodicals, making a total of 186 new publications. The industry has not recorded any sustained growth since the mid1970s. For the industry to develop, several things must be done. Firstly, publishers must unite if their association is to become strong. Past differences that existed have disappeared as those in the industry, including parastatal publishing firms, have realised that dialogue and not acrimony is the key to solving the many problems that beset the industry.

All the multinationals, Longman, Evans and Heinemann have sold some of their equity to local Kenyans - a controlling interest in the case of the latter. Oxford University Press is registered in Kenya as a charity, and ploughs back whatever profits it makes into new projects. The Board of Macmillan Kenya is chaired by a Kenyan. On the other hand, state publishers such as the Jomo Kenyatta Foundation and the Kenya Literature Bureau are under government pressure to be profitable if their continued survival is to be justified. So all Kenya publishers, including indigenous publishing entrepreneurs, now have a profit motive. To be able to encourage a healthy and lively industry, the government could assist by not showing favouritism towards state publishers as it is doing at present. The policy should be to allow free enterprise and let the best book survive in the market.

Kenya is fortunate to have a paper mill which is currently increasing its capacity by 30,000 tons so that it can satisfy the market's demand for 100,000 tons of paper per year. Only a small fraction of this tonnage goes towards book manufacture, of course, the bulk of it serving the packaging industry. The country is also fortunate to have a reasonably good infrastructure of roads, railways, post offices, etc., and over 200 bookshops, so that book distribution is less of a headache than in other African countries. The authors are there and can be trained and guided in the art of writing. Co-operation between authors, publishers, paper manufacturers, printers, booksellers, libraries and the government could eliminate the mutual suspicion which currently exists, and would create a climate more conducive to the elimination of illiteracy and the creation and strengthening of book-reading and bookbuying habits.

The seminar to relaunch the Kenya National Book Development Council held in July 1988, sponsored by UNESCO and the Ministry of Education, attracted participants from all areas of the book trade and representatives from the relevant government ministries. This is clearly a move in the right direction. If all these bodies work together in harmony, publishing in Kenya will have been injected with a new lease of life.

\section{The present}

The Kenya publisher operates in difficult circumstances and faces many problems and challenges, some of which are not within his scope to solve. Firstly, he is under-capitalised and cannot afford to make mid-term to long-term investments. The commercial banks are reluctant to lend to him - they consider publishing a risky and unviable business and do not accept stocks of backlist titles as adequate security. As a result Kenyan publishers are not enterprising enough; instead of diversifying their lists to cater for neglected areas such as children's books, fiction, academic books, and books in mother tongues, they are all competing for a share of the educational book market where sizeable sales are possible because of a gullible and captive examination-conscious market.

Secondly, even though they share the same destiny, Kenyan publishers are not united. There has always been a tug-of-war between the local branches of multinational publishers, the entrepreneurial indigenous publishers, the religious publishers and the state publishing 
corporation. Consequently, there is no strong publishers' association in the country, unlike the case of booksellers, librarians, and printers, whose associations are active in protecting the interests of their members.

\section{(a) Children's books}

Before we deal with those factors which are outside the control of the Kenyan publisher, but which affect his business, a discussion of children's book publishing will help to highlight the problems.

The area of publishing for children is one of those that have been ignored in the publishers' rush for short-term projects with immediate returns. Children's books are difficult and expensive to produce. They call for clear, eye-catching illustrations, colour-printing, tough paper and case-binding. Attempts by local publishers to break into this market have so far not proved successful. EAPH, which went bankrupt in 1987, had a series of children's books called The Lioncub Series in which it had published over ten titles, and The Longman Reading Scheme, consisting of such titles as Hare is Here, Hare is Bad, etc., written by Dorothy Bracey and Peter Lieta, and illustrated by Peter Hurst, and which seemed to hold out great possibilities. The series had a standard format and design and the books were carefully graded to a progressive and rising level of difficulty. However, this series has not done well. Both Transafrica Publishers and Njogu Giten Publications, who had each launched a series of children's books during the mid-1970s, are no longer in business.

The booklists that are sent out to parents every year consist of imported books: Enid Blyton's Famous Five stories, the Nancy Drew Series, the Hardy Boys, Topsy and Tim, fanet and fohn, Reading 360, and so on. And whenever my children ask me for money to buy a book for leisure reading, they always bring home a Mills and Boon or a Sweet Dreams. In a keynote address in Harare last year, Professor Chinua Achebe described this imported literature as 'beautifully packaged poison', and called upon every African parent to write at least one book for his child. Heinemann Kenya took up this challenge and have launched two series of children's books, Elementary Readers and funior Readers, and have already issued three of Achebe's children's books in these series. Asenath Odaga of Lake Publishers is also issuing children's books. Two associations, the Children's Literature Association of Kenya (CLAK) and the Council for the Promotion of Science Publications for Children in Africa (CHISCA), were formed in 1988 with a view to promoting fiction for children - science publications for children in the case of the latter body. But this is an area where publishers might require government support if their efforts are to suceed. If the government pledged to buy, say, 3,000 copies of every new children's book published in Kenya, the present stranglehold by foreign children's books might be abated.

Further, if local prizes were set up for the best writers of children's books and the best illustrators, this might help draw out the best that Kenya is capable of. I am, of course, aware of the Noma Award, but this is an Africa-wide prize, and is not restricted to childrens's books only, although one of the winners, Meshack Asare of Ghana, is a writer of children's books. More specific prizes with a direct focus on children's book writers and illustrators would achieve better results.

\section{(b) Language policy}

Here, I will quote from my own paper, 'Publishing in a Multi-lingual Situation: The Kenya Case', presented at a UNESCO-sponsored seminar in Moscow in 1976 and published in the April 1977 issue of the African Book Publishing Record ( $A B P R$ ). In it, I bemoan the lack of a clear-cut language policy, and indeed the lack of a national publishing or book policy:

Kenya's post-independence language policy is laid out in the Ominde Commission's Report of 1964. This report, while recognising the importance of the other languages, 
concluded that 'the majority ... wished to see the universal use of English language as the medium of instruction from Primary 1', and proceeded to give reasons as follows:

'First, the English medium makes possible a systematic development of language study and literacy which would be very difficult to achieve in the vernaculars. Secondly, as a result of the systematic development possible in the English medium, quicker progress is possible in all subjects. Thirdly, the foundation laid in the first three years is more scientifically conceived and, therefore, provides a more solid base for all subsequent studies, than was ever possible in the old vernacular teachings. Fourthly, the difficult transition from a vernacular to English medium, which can take up much time in Primary $\mathrm{V}$, is avoided. Fifthly, the resulting linguistic equipment is expected to be much more satisfactory, an advantage that cannot fail to expedite and improve the quality of postprimary education of all kinds. Lastly, advantage has been taken of the new medium to introduce modern infant techniques into the first three years, including activity and group work and a balanced development of muscular co-ordination. In short (the report concluded), we have no doubt of the advantage of English medium to the whole educational process.'

About Kiswahili, the Commission reported that 'those giving evidence were virtually unanimous in recommending a general spread of this language, not only to provide an additional, and specifically African, vehicle for national co-ordination and unification, but also to encourage communication on an international basis, not only within East Africa, but also within the Eastern parts of the Congo and parts of Central Africa'.

Kiswahili is, therefore, recognised both as a unifying national influence and as a means of pan-African communication over a considerable part of the continent. In view of these important functions, the Commission believed that Kiswahili should be a compulsory subject in the primary schools.

As regards African languages, the Commission's views were mixed although there was a general recommendation that one or two subjects per day should be devoted to these languages in the curriculum of all primary schools. This was followed up by a circular from the Chief Inspector of Schools in 1965, which reminded all schools of the importance of teaching African languages as a subject.

The Ominde Report, in effect, sanctioned the use of English, advocated the teaching of Kiswahili and supported the use of African languages in the Kenyan school system. The existence of the three languages categories alongside one another, albeit with varying emphasis and application, has created problems not only in the educational structure, but in the production of books as well.

\section{(c) Libraries}

Here I will quote an extract from my monograph Books and Reading in Kenya, commissioned by UNESCO and published in 1983 in their Studies on Books and Reading Series:

One of the aims of the now defunct East African Literature Bureau was to encourage the distribution of books to African readers, the majority of whom were to be found in the rural areas. To achieve this aim, E.A.L.B. launched a library system in the 1950 s through which the people of the partner states could get access to books through postal borrowing and mobile book vans, while plans for the building of libraries in selected centres were being worked out. At the attainment of independence in 1964, the library division of E.A.L.B. became the Kenya National Library Service.

Today, K.N.L.S., with a chain of branch libraries in Eldoret Embu, Garissa, Kakamega, Kisumu, Mombasa, Nakuru, Nyeri, Thika and with new ones shortly to be 
opened in Kericho and Kisii, is the largest and most extensive library net-work in the country. It has 84,309 volumes and seating capacity of 250 at its Nairobi headquarters, and a total of 265,000 volumes and 1,900 seats in all the branches put together.

The libraries in Kericho and Kisii are now fully operational. In addition, new ones have been constructed in Kabarnet and Meru, bringing the total number to 15. They are still determined to achieve their aim of having one National Library per district. In addition, it operates 7 mobile libraries which ply the remote areas of the country, visiting rural centres, lending out books and advising on their use. K.N.L.S. has plans to set up a public library in each of the country's 40 district centres during the next ten years, and it is hoped that the government will provide the necessary funds to make possible the realisation of this goal.

\section{(d) Other factors}

The other problems include illiteracy (officially acknowledged to be 53 per cent), and lack of voluntary book-buying and book-reading habits. There are many people whom I have referred to elsewhere as 'illiterate graduates', since none of them has ever read further than the daily newspaper since they left university. Illiteracy itself is a problem which only the government can tackle, as it requires mass mobilisation of people and resources if every Kenyan has to be literate by the year 2000, as the Ministry of Education has promised.

And finally, since the break-up of the East African Community in 1977, exacerbated by the shortage of foreign exchange, particularly in Uganda and Tanzania, the market has shrunk considerably. As a result of this, books have become more expensive as economies of scale do not allow reduced unit costs.

The setting-up of the Preferential Trade Area (PTA) Treaty covering seventeen countries in East and Central Africa, whereby a clearing bank will be established and special tariffs will apply to member states, might bring some relief but this is not yet fully operational, and I do not yet know of any PTA deal that has involved books. However, this development, if it works, holds out great possibilities for book circulation in East, Central and Southern Africa.

What then, are the future prospects of publishing in Kenya, one may ask? The answer is, the prospects are good but we have not had a great novel coming out of Kenya in these last few years. Ngugi wa Thiong'o, Kenya's leading fiction writer, is living in exile. The Mau Mau theme, which formed the inspiration for most of Kenya's scholars and writers of fiction, is nearly exhausted. Good fiction arises from a deep traumatic situation either at the personal or the social level. The peace and tranquillity currently prevailing in the country cannot produce a great novel, but they can generate good drama, as one witnesses in the annual Kenya Schools Drama and Dance Festivals. As for autobiographies, biographies and memoirs, most of Kenya's leaders are still young and might not consider writing their memoirs until they are over seventy. The level of literacy is growing gradually and Kenyans are slowly being inculcated into book-reading and book-buying. As people's standard of living improves, and a leisured middle class that can find time and money develops, publishing will find itself playing an increasingly important role. So, in spite of the present difficulties, some of which are already being tackled at government and private-sector level, the future is bright. 


\section{References}

Altbach, P. 1977. Publishing in the Third World

Chakava, H. 1977. 'Publishing in a multi-lingual situation: the Kenya case'. $A B P R, \operatorname{III}(2)$. 1982. A National Book Strategy for Kenya. UNESCO.

1983. Books and Reading in Kenya. UNESCO.

1988. 'A decade of publishing in Kenya: one man's involvement'. $A B P R, \mathrm{XIV}(4)$.

Chege, J.W. 1978. Copyright Law and Publishing in Kenya. EALB.

Ndegwa, J. 1972. 'Printing and Publishing in Kenya: an Outline of Development'. An essay submitted as part of the Degree of MA in Librarianship of the University of London.

Nottingham, J. 1967. 'Whose books build which nation?'. East African fournal.

Richards, C. G. 1964. 'The place of books in developing regions'. East African fournal. Swainson, N. 1980. The Development of Corporate Capitalism in Kenya. HEB. 